\title{
Role of atd Angle of Palm in Diagnosis of Pulmonary Tuberculosis
}

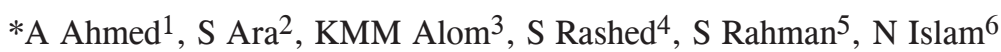

\begin{abstract}
Background: Dermtoglyphics are the lines and ridges forming a skin pattern, especially on the palm of the hands, fingertips and soles of feet. Differentiations of dermal ridges in early life are genetically determined1. Any disturbance by genetic factors causes development of unusual dermatoglyphics. On the other hand, deficiency of Mannose binding protein (MBP) gene and Interleukin-1 (IL-1) gene cause spread of pulmonary tuberculosis2. The dermatoglyphic pattern in patient with pulmonary tuberculosis can represent an anatomical, non-invasive, inexpensive tool for screening high-risk population, and facilitates early prediction of vulnerable population of PTB.
\end{abstract}

Materials and Methods: A Cross-sectional, analytical type of study was conducted in Department of Anatomy, Dhaka Medical College, Dhaka, from January 2012 to December 2012. The study was performed in 100 patients suffering from pulmonary tuberculosis and 100 healthy individuals.

Results: There was significant reduction in mean \pm SD of atd angle in pulmonary tuberculosis patients in comparison to control subjects. Mean \pm SD of atd angle was $37.87 \pm 3.403$ in pulmonary tuberculosis patients and $49.77 \pm 4.628$ in the control subjects. The difference was highly significant $(\mathrm{P}<0.001)$.

Conclusion: The atd angle was found significantly narrower in the study group compared to the control subjects.

Key Words: Dermatoglyphic, pulmonary tuberculosis, axial triradius, atd angle.

\section{Introduction}

The skin of the palm of the hands and the plantar surface of feet is designed and corrugated with the ridges $^{3}$. The epidermal ridges of these region form different types of configuration. These configurations of epidermal ridges of palms, fingers and soles are known as dermatoglyphics. Cummin in 1926. first time added the term dermatoglyphics to the field of science. The study of dermatoglyphics was pioneered by Sir Francis Galton (1892) ${ }^{4}$. After having a good grip on the basics of dermatoglyphic, the icons of this field were inspired to search and investigate its correlation with various types of diseases like -depression, schizophrenia, epilepsy, psoriasis, leprosy, Down's syndrome, Klinefilter's

$1 *$ Dr. Afrose Ahmed, Assistant Professor, Department of Anatomy, Anwer Khan Modern Medical College, Dhanmondi, Dhaka

${ }^{2}$ Prof. Shamim Ara, Professor and Head, Department of Anatomy, Dhaka Medical College, Dhaka

${ }^{3}$ Dr. K M Monjurul Alom, MD (Pulmonology) Resident - phase B, National Institute of Diseases of the Chest and Hospital (NIDCH), Mohakhali, Dhaka

${ }^{4}$ Dr. Saida Rashed, Assistant professor, Deparrtment of Anatomy, Medical College for Women and Hospital, Uttara, Dhaka

${ }^{5}$ Dr. Sadia Rahman, Assistant professor, Deparrtment of Anatomy, Ibrahim Medical College, Shahbag, Dhaka

${ }^{6}$ Dr. Nadia Islam, Assistant Professor, Department of Pharmacology, Anwer Khan Modern Medical College, Dhanmondi, Dhaka

*Corresponding Author

Date of submission: 10.08.2016, Date of acceptance: 15.01.2017 
syndrome and many more other medical conditions e.g- diabetes, hypertension, coronary artery disease, bronchial asthma, pulmonary tuberculosis, carcinoma breast etc ${ }^{5,6}$.

The epidermal ridges produce grooves on the surface of the palm. In the palm in relation to the base of the II, III, IV and V digit a,b,c, and $\mathrm{d}$ triradius are located respectively. Axial triradii or ' $t$ triradii' usually found in the axis of the $4^{\text {th }}$ digit. Cummin and Midlo in 1961 stated that axial triradii lies commonly near the point where the palm is connected to the wrist, in the interval between thenar and hypothenar eminences ${ }^{7}$. The atd angle is formed by drawing lines from 'triradius a' to axial or 't triradius' and from 'triradius $\mathrm{d}$ ' to axial or 't triradius'. The atd angle averages about $48^{\circ}$ among the normal individuals. Atd angle is measured in adducted palm. The abducted palm gives more measurement by $10^{\circ}$. The instruction for determining the atd angle of the palm was given by Panrose in $1954^{6}$.

The patterns of ridges that develop in the palm are determined genetically ${ }^{8}$. Once established, dermatoglyphic patterns remain unchanged throughout life except in the dimension in commensurate to the growth of an individual ${ }^{3}$. Any disturbance by genetic factors can produce unusual or abnormal dermatoglyphics during intrauterine life ${ }^{9}$.

Pulmonary tuberculosis (TB) is an infectious disease caused by Mycobacterium tuberculosis. The genetic contribution is one of the causes of pulmonary tuberculosis. Susceptibility to pulmonary tuberculosis has been linked to Mannose binding protein gene and IL-1 gene cluster4. After entering into the body, mycobacterium tuberculosis is ingested by macrophages. Interleukin-1 (IL-1) and gamma interferon (IFN- $\gamma$ ) genes cause formation of phagolysosome and also by production of nitric oxide causes destruction of mycobacterium tuberculosis from cell wall to $\mathrm{DNA}^{10}$. Thus deficiency of Mannose binding protein gene and IL1 gene cause spread of infection. On the other hand, as the finger print and palm print have a genetic bases, deficiency of these genes causes development of unusual dermatoglyphics.
Tuberculosis is a major global health problem especially in the developing countries, like Bangladesh. In "Fifth Joint Monitoring of the Bangladesh National Tuberculosis Control Program 2-12 October 2010" by WHO reported that in 2008 there were approximately 660,000 TB cases (range $420,000-980,000$ ) in the country and about 79,000 patients (range 31,000 - 150,000) were died from TB 11 . According to "WHO report 2011 - Global Tuberculosis control" -TB is more common in men than in women and affects mostly adult in the economically productive age group around 15 to 59 years ${ }^{12}$. According to "National Tuberculosis Control Program -2009" of Bangladesh by WHO reported that approximately 875 new TB cases and 180 TB deaths occur daily in the country. To reduce the suffering from tuberculosis, development of new tools is necessary for early prediction of TB. The findings of the study will be useful in early prediction of pulmonary tuberculosis to the Pulmonologists.

\section{Materials and Methods}

The study was performed in 200 individuals. Among them, 100 were patients suffering from pulmonary tuberculosis and 100 were healthy individuals (not suffering from pulmonary tuberculosis) who served as control group. The patients suffering from pulmonary tuberculosis were selected from diagnosed cases. Diagnosis was done by the pulmonologist of National Institute of Diseases of the Chest and Hospital (NIDCH), Mohakhali, Dhaka. Diagnosis of the patients were based on - Sputum for AFB and Mantoux test $(+) v e$, and X-ray chest revealed features of pulmonary tuberculosis. The control group was selected from National Institute of Diseases of the Chest and Hospital (NIDCH), Mohakhali, Dhaka. They attended the outpatient department of NIDCH with history of cough/ fever / chest pain. They were not suffering from pulmonary tuberculosis and were confirmed by the pulmonologist of that institute. They were sputum for AFB and Mantoux test(-)ve and in their chest X-ray, no abnormality was detected. The control group had no history of known contact with pulmonary tuberculosis patient. Data sheets of personal information were filled up 
for both groups to avoid duplication and to exclude diseases like diabetes mellitus, hypertension, congenital heart disease, neurological disorders, asthma, carcinoma breast etc from history. Those individuals who were suffering from any of these diseases were excluded from sample. All the individuals (patient or control) were informed by explaining about the nature of the work. Then written consent was taken from the individual. Data was collected with due permission from the Director of National Institute of Diseases of the Chest and Hospital (NIDCH), Mohakhali, Dhaka.

The materials used in present study were white paper, a clip board, printing ink, hand roller, a flat bottom container, optical grade hand lens with $4 \mathrm{X} \&$ 6X magnification, protractor, scale, spirit or turpentine oil and liquid soap. Dermatoglyphic print of palm was taken by the "Ink \& paper Method" as described by "Cummin (1936)" and "Cummin and Midlo (1961)".

The position of "axial or $t$ triradius" was identified first and then the "triradius a" and "triradius d" were located by the hand lens. Then the atd angle was drawn by joining lines from "triradius a" to "axial or $\mathrm{t}$ triradius" and from "triradius $\mathrm{d}$ " to "axial or

$\mathrm{t}$ triradius". atd angle was measured with the help of a protractor in the palm. Atd angle was measured in right and left hand separately. Then two values were summed to get single value for an individual. Then the mean values were calculated for different group ${ }^{7}$.

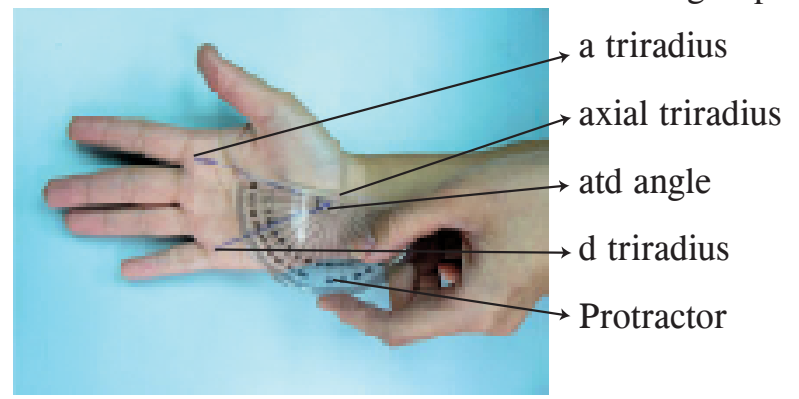

Fig 1:- Showing process of measurement of "atd angle"13.

Data were analyzed with the help of SPSS (Statistical Package for Social Science) program. For quantitative data Unpaired Student's 't' test

\section{Ethical Clearance}

The thesis work was carried out after the approval by the Ethical Review Committee of Dhaka Medical College, Dhaka.

\section{Results}

In pulmonary tuberculosis patients, atd angle ranged from $30^{\circ}$ to $56^{\circ}$ and mean \pm SD was $37.87 \pm 3.4$. In the control group, atd angle ranged from $34^{\circ}$ to $60^{\circ}$ and mean \pm SD was $49.77 \pm 4.6$. atd angle in control subjects was higher than the pulmonary tuberculosis patients $(\mathrm{P}<0.001)$. [Shown in Table 1, and Fig 2]

Table I : atd angle in pulmonary tuberculosis patients and control subjects.

\begin{tabular}{|ccccc|}
\hline \multirow{2}{*}{ Group } & $\begin{array}{c}\text { No. of } \\
\text { subjects (n) }\end{array}$ & \multicolumn{2}{c|}{ atd angle } & P value \\
\cline { 3 - 4 } Patient & 100 & $37.87 \pm 3.403$ & $30-56$ & \\
Control & 100 & $49.77 \pm 4.628$ & $34-60$ & 0.001 *** \\
\hline
\end{tabular}

Comparison of atd angle between pulmonary tuberculosis patients and control subjects was done by Unpaired student's 't'test. $* * *=$ highly significant.

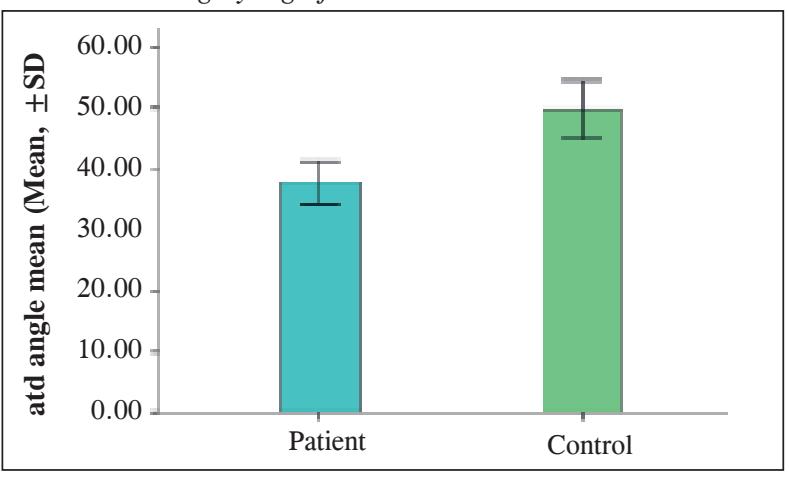

Fig 2: atd angle in pulmonary tuberculosis patients and control subjects.

\section{Discussion}

Mean \pm SD of atd angle in pulmonary tuberculosis patients was $37.87 \pm 3.4$ in the present study. In the control group, mean \pm SD of atd angle was 49.77 \pm 4.6. atd angle in control subjects was higher than the pulmonary tuberculosis patients $(\mathrm{P}<0.001)$.

Sangita S. Babu, B. P. Power, O. N. Khare (2006) in Madhay prodesh, India reported highly significant difference of atd angle in pulmonary tuberculosis patients and in normal individuals $(\mathrm{P}<$ 0.02 ). They observed Mean \pm SD of atd angle in pulmonary tuberculosis patients was $38 \pm 3.77$ and 
in the control group, mean $\pm \mathrm{SD}$ of atd angle was $43.6 \pm 5.564$. In comparison of findings of their study with the findings of present study, similarity was found with the patient group $(\mathrm{P}>0.05)$ and dissimilarity with the control subjects $(\mathrm{P}<0.001)$.

\section{Conclusion}

There was significant reduction of mean \pm SD of atd angle in pulmonary tuberculosis patients (37.87 $\pm 3.403)$ as compared to control subjects (49.77 $\pm 4.628)$. The difference was highly significant $(\mathrm{P}<0.001)$. These parameters may help in early prediction of pulmonary tuberculosis in a patient.

\section{References}

1. Sreenivasulu K. et al. A study of palmar dermatoglyphics of bronchial asthma patients and their first degree relatives in Kurnool district, Indian Journal of Allergy, Asthma and Immunology. Jan-June, 2012; 36(1), 2-5.

2. Chandhari, J., et al. A study of palmer Dermatoglyphics of Pulmonary Tuberculosis Patients in Bhavnagar District. NJIRM, April- June, 2011; 2 (2), 50-52.

3. Kumbnani, H. K. Dermatoglyphics: A Review, Anthropology Today: Trends Scope and Applications. Anthropologist Special, 2007; 3, 285-95.

4. Babu, S. S., Powar ,B.P. and Khare, O.N,. Palmar Dermatoglyphics in Pulmonary Tuberculosis. Journal of Anatomical Society, India, 2005; 54 (2), 64-66.

5. Gupta, U.K. and Prakash, S. Dermatoglyphics: a study of finger tip patterns in bronchial asthma and its genetic disposition. Kathmandu University Medical Journal, 2003; 1 (4), 267-71.

6. Mellor C.S., 1968. Dermatoglyphic in Schizophrenia: Part I: Qualitative Aspects. BJ Psych The British Journal of Psychiatry [on line] Available at http: //bjp.rcpsych.org/ site/ subscriptions/ [accessed 15 December, 2012]

Mellor C.S., 1968. Dermatoglyphic in Schizophrenia: Part II: Quantitative study. BJ Psych The British Journal of Psychiatry [on line] Available at http: //bjp.rcpsych. org/site/ subscriptions/ [accessed 15 December, 2012]
7. Fogle Thomas, 1990. Using Dermatoglyphics from Down Syndrome and Class Populations to Study the Genetics of a Complex Trait. [Online] Association for Biology Laboratory Education (ABLE). Available at: http:// www.zoo.utoronto.ca/able [accessed 17 December, 2012]

8. Moore Keith L., Persaud T.V.N. and Torchia Mark G., 2009. The Developing Human Clinically Oriented Embryology, 8th ed. U.P. India: Elsevier.

9. Elsaadany, H.M., Kassem ,E., El-Sergany, M. and Sheta, A. A.R. Can Dermatoglyphics be used as an Anatomical Marker in Egyptian Rheumatoid Patients? . Journal of American Science, 2010; 6(11), 457-66.

10. Mc Adam, A. J. and Sharpe, A. H., Infectious Diseases. In: V. Kumar, A.K. Abbas, N. Fausto, ed. 2010. Robbins and Cotran Pathologic Basis of Disease. Philadelphia, Pensylvania: Elsevier Saunders. ch-8, 366-67.

11. World Health Organization country office for Bangladesh, 2-12 October 2010. Fifth Joint Monitoring Mission of the Bangladesh National Tuberculosis Control Programme. Regional office for South-East Asia, Indraprasha Estate, Mahatma Gandi Marg, New Delhi 110002, India. World Health Orgization. Available at: http: // www. who. int/ tb/ country/data / download / en/ index.html. [Accessed 12 June 2012].

12. World Health Organization, 2011. WHO Report 2011 Global Tuberculosis Control. 20 Avenue Appia, 1211 Geneva 27, Switzerland. World Health Organization. Available at: www. who.int / tb / publications / global_report/. [Accessed 12 June 2012].

13. Bonnevie, K., 1929. Image for palmar dermatoglyphics. [ Image online ] Available at: handfact. Files. Wordpress. Com / 2011 / $01 /$ atd - angle - measurement. jpg. 